\title{
Avidity of antineurocytoskeletal antibodies in Alzheimer's disease patients
}

\author{
Libuse Noskovaa , Lenka Fialova ${ }^{\mathrm{a}}$, Ales Bartos ${ }^{\mathrm{b}, \mathrm{c}}$, Tomas Zima ${ }^{\mathrm{a}}$
}

\begin{abstract}
Aims. To optimise the ELISA method for the avidity of $\mathrm{IgG}$ antibodies against neurofilament heavy chain $(\mathrm{NfH})$ and to determine the levels and avidity of anti-NfH antibodies in patients with Alzheimer's disease (AD) and a healthy control group.

Methods. Various dilutions of sera and concentrations of urea and sodium chloride as chaotropic reagents were tested in the process of the ELISA optimisation. The levels and avidity of anti-NfH antibodies were determined in 30 patients with Alzheimer's disease and 30 age-matched cognitively normal elderly adults.

Results. Sera dilution 1:200 and urea as a chaotrope in a concentration $6 \mathrm{~mol} / \mathrm{L}$ were chosen to be the most suitable for the avidity assay of anti-NfH antibodies by ELISA. The results showed no differences in either level or avidity of IgG anti-NfH antibodies between AD patients and cognitively normal persons. The levels of anti-NfH IgG antibodies inversely correlated with their avidities.

Conclusions. We optimised the ELISA method for the determination of anti-NfH antibody avidity determination which is suitable for research of anti-NfH antibody avidity in patients with neurological diseases associated with neurocytoskeletal defects. The determination of serum anti-NfH antibody avidity in AD patients seems to have limited diagnostic significance.
\end{abstract}

Key words: Alzheimer's disease, antibodies, avidity, heavy chain of neurofilament, neurofilament

Received: December 14, 2016; Accepted: March 24, 2017; Available online: April 26, 2017

https://doi.org/10.5507/bp.2017.017

anstitute of Medical Biochemistry and Laboratory Diagnostics, First Faculty of Medicine, Charles University and General University Hospital in Prague, Czech Republic

${ }^{b}$ National Institute of Mental Health, Klecany, Czech Republic

'Department of Neurology, Third Faculty of Medicine, Charles University and Faculty Hospital Kralovske Vinohrady, Prague, Czech Republic Corresponding author: Libuse Noskova, e-mail: Noskova.Libuse@seznam.cz

\section{INTRODUCTION}

Alzheimer's disease (AD) is the most frequent neurodegenerative disorder. Various alterations in the neurocytoskeleton are associated with the neurodegenerative process $^{1,2}$. When the axon is damaged or neurodegeneration is initiated, the structures of the neuronal cytoskeleton normally localised inside in neurons are released from the neurons into the interstitial fluid, cerebrospinal fluid and bloodstream.

The cytoskeletal proteins in the extracellular space as a result of various pathological processes may interact with the cells of the immune system and induce an inflammatory or autoimmune response ${ }^{3}$. The levels of autoantibodies against neurocytoskeletal autoantigens in the serum might be potential biomarkers for neurodegenerative diseases involving continuous neuronal death $\mathrm{h}^{4,5}$. Moreover, the study of autoantibodies is becoming important in association with intensive investigation and clinical trials testing the possibility of immunotherapy in $\mathrm{AD}\left(\right.$ ref. $\left.^{6}\right)$.

In addition to the changes in antibody levels, their avidity is a substantial qualitative characteristic and could also be of clinical significance ${ }^{7-9}$. The examination of antibody avidity in clinical practice is usually used for the differentiation of primary and chronic infection ${ }^{10}$ or for monitoring the effectiveness of vaccination ${ }^{11-13}$.

Current knowledge about the avidity of autoantibodies is less complex than that about antibodies against exogenous antigens. High-avidity autoantibodies may be associated with autoimmune processes in the organism ${ }^{7,9,14}$, but decreased avidity of antibodies against the $\beta$-amyloid protein in Alzheimer's disease has also been described ${ }^{15}$. However, information about the avidity of neuron-specific antibodies is sporadic so far, although it is a relevant issue of antibodies, which may determine their protective or injurious potency.

Recently, we found increased levels of intrathecally synthesised antibodies against $\mathrm{NfH}$ and tau proteins in patients with Alzheimer's disease ${ }^{16}$. Serum levels of anti$\mathrm{NfH}$ IgG antibodies in $\mathrm{AD}$ have also been studied ${ }^{16,17}$, but we are not aware of any study evaluating the avidity of these antibodies. Therefore we decided to continue with a more detailed study of anti-NfH IgG antibodies in serum by the determination of their avidity in the patients with dementia.

The aim of this study was to design and optimise ELISA for the determination of anti-NfH IgG antibody avidity. Various methods and procedures for the measurement of antibody avidity have been designed. One of 
the methods suitable for clinical use is ELISA (EnzymeLinked Immuno-Sorbent Assay), which is modified by the addition of substances with a chaotropic effect on the immune complexes formed during the ELISA procedure $^{18}$. These agents are necessary for the disruption of the immune complexes containing weakly bound antibodies. The lower the antibody avidity is, the more immune complexes are disrupted and the released antibodies are then washed away after incubation with the chaotropic agent.

Using our optimised ELISA, we evaluated the avidity of the anti-NfH IgG antibodies in the serum of patients with Alzheimer's disease and an appropriate control group. We aimed to better characterise the humoral immune response against neurocytoskeletal components and to consider a possible diagnostic significance of anti-NfH IgG antibody avidity.

\section{MATERIAL AND METHODS}

\section{Participants}

We examined two groups of elderly persons. Serum samples were obtained from patients at the Department of Neurology, Charles University. The AD patients were recruited from the Memory Clinic. The diagnosis was based on objective evidence of a progressive decline in cognition, functional and detailed neuropsychological as sessments, hippocampal atrophy seen on brain magnetic resonance imaging (or computer tomography in case of contraindications), temporo-parietal hypoperfusion seen using single photon emission computed tomography, or increased total or phosphorylated tau proteins and/or decreased $\beta$-amyloid concentrations in cerebrospinal fluid using cut-offs established in our previous studies ${ }^{19-21}$. The diagnosis of dementia due to AD had been already established before blood sampling ${ }^{22-24}$. They had mild form of dementia according to MMSE scores (Tab. 1). Many of them have already died after long-term clinical decline. Subjects in the control group $(n=30$; mean age 72 years) were cognitively normal elderly adults having normal Mini-Mental State Examination (MMSE) scores ${ }^{25}$. They were age-matched with the AD patients.

Table 1. Sociodemografic characteristics of participant groups.

\begin{tabular}{lcc}
\hline & Controls & $\begin{array}{c}\text { Alzheimer's } \\
\text { disease } \\
\text { patients }\end{array}$ \\
\hline Number of patients & 30 & 30 \\
Age at blood draw (years) & $72 \pm 5$ & $74 \pm 8$ \\
Gender & $63 \%$ females & $77 \%$ females \\
Education (years) & $15 \pm 3$ & $13 \pm 3$ \\
MMSE score (0-30 points) & $29 \pm 1$ & $19 \pm 6$ \\
\hline
\end{tabular}

Data are expressed as average $\pm \mathrm{SD}$

MMSE - Mini-Mental State Examination score
The basic characteristics of the two groups are shown in Table 1. The AD patients and patients in the control group did not differ in age and other parameters correlates with epidemiological findings ${ }^{26}$.

Patients included in the study signed the informed consent. The study was approved by the Ethics Commitee of the Third Faculty of Medicine, Charles University.

Only selected samples were used for the optimisation of ELISA. The influence of $\mathrm{pH}$ was tested in five samples (control and AD patients' samples). A comparison of chaotropic agents was performed in 20 samples ( 10 controls and $10 \mathrm{AD}$ patients).

\section{Methods \\ ELISA for anti-NfH IgG antibody level and avidity determination in the serum}

Anti-NfH antibody IgG levels were determined by ELISA originally described by Silber et.al. ${ }^{27}$ and later modified for the purpose of our previous studies ${ }^{28,29}$.

Two kinds of chaotropic agents - $\mathrm{NaCl}$ and urea in various concentrations were tested for avidity method optimisation. Solutions at different concentrations were chosen for initial experiment concentrations based on previous works ${ }^{29,30}$. Solutions of $\mathrm{NaCl}$ were used at concentrations $0.25 \mathrm{~mol} / \mathrm{L}, 0.5 \mathrm{~mol} / \mathrm{L}, 1.0 \mathrm{~mol} / \mathrm{L}, 2.0 \mathrm{~mol} / \mathrm{L}$ and $3.0 \mathrm{~mol} / \mathrm{L}$ and urea at $2.0 \mathrm{~mol} / \mathrm{L}, 4.0 \mathrm{~mol} / \mathrm{L}, 6.0 \mathrm{~mol} / \mathrm{L}$ and $8.0 \mathrm{~mol} / \mathrm{L}$. Since $\mathrm{pH}$ values change in the chaotropic agent solutions of different concentrations, we also tested the influence of $\mathrm{pH}$ on the avidity determination. Therefore, the avidity experiments were performed with the chaotropic agent solution both at the actual (original) $\mathrm{pH}$ and at $\mathrm{pH}$ adjusted to the uniform value of 7.4. Serum samples were analysed in serial dilution from 1:50 to $1: 400$.

\section{Procedure of ELISA for the determination of anti-NfH IgG antibody levels and their avidity}

The heavy neurofilament subunit isolated from a bovine spinal cord (purity is $>98 \%$, declared by the manufacturer, Progen, Germany) was used as the antigen. An aliquot from the stock solution of the antigen was diluted in carbonate immobilisation buffer $\left(10 \mathrm{mmol} / \mathrm{L} \mathrm{NaHCO}_{3}\right.$, $\left.0.15 \mathrm{mmol} / \mathrm{L} \mathrm{NaN}_{3}, \mathrm{pH} 9.6\right)$ to the concentration of $2.5 \mu \mathrm{g} / \mathrm{mL}$. One half of the wells of 96-well plate type Maxisorp (Nunc, Denmark) was coated with $100 \mu \mathrm{L}$ of diluted antigen and the other half of the wells was coated only with immobilisation buffer. The plate was incubated overnight at $4{ }^{\circ} \mathrm{C}$.

After the binding of the antigen, the wells were washed (wash solution $0.1 \mathrm{M} \mathrm{NaCl}+$ Tween 20) and blocked with 1\% BSA (bovine serum albumin) fraction V in PBS (phosphate buffered saline), $\mathrm{pH}$ 7.4. Then, the serum samples in appropriate dilution (in $1 \% \mathrm{BSA}$ fr. $\mathrm{V}$ in PBS) were applied in an amount of $100 \mu \mathrm{L}$. Serum samples were incubated in the wells for 2 hours at room temperature.

After five washings of the wells, the chaotropic agents $\mathrm{NaCl}$ or urea in tested concentrations or PBS alone were applied to the appropriate wells in an amount of $100 \mu \mathrm{L} /$ well. It was followed by incubation for 10 minutes at room temperature. The wells were washed $(4 \times)$. 
$100 \mu \mathrm{L} /$ well of secondary antibody (conjugate) against the Fc region of human immunoglobulin $\mathrm{IgG}$ conjugated with peroxidase (Southern Biotech, USA, diluted 5000x in $1 \%$ BSA fr. V in PBS) was added to the wells in the next step and incubated for one hour at room temperature. After washings $(4 \times), 100 \mu \mathrm{L}$ of peroxidase substrate TMB (tetramethylbenzidine) with $\mathrm{H}_{2} \mathrm{O}_{2}$ (TestLine, Czech Republic) was added to the wells. The enzyme reaction was stopped by adding $2 \mathrm{~mol} / \mathrm{L} \mathrm{H}_{2} \mathrm{SO}_{4}(100 \mu \mathrm{L} /$ well $)$ after incubation for 15-20 min at room temperature in the dark. Absorbance (A) of the wells was measured at $450 \mathrm{~nm}$ against a reference wavelength of $620 \mathrm{~nm}$ using a Tecan Sunrise Plate Reader (Tecan, Austria) with the Magellan 6 program.

The absorbance of the blank sample (serum replaced with diluent) was subtracted from the absorbance value of each sample. For comparative purposes, the same pooled serum was used as the internal control in all analytical series of patients' samples $(n=60)$. The intra- and inter-assay of the ELISA method did not exceed $10 \%$.

\section{Expression of anti-NfH IgG antibody concentration}

Because no appropriate generally-used standards are available for anti-NfH IgG antibodies, a pooled serum prepared by mixing sera from patients with high levels of anti-NfH IgG antibodies (according their absorbance in the previous ELISA determination) served as a calibration standard for the determination of the arbitrary units (AU) of anti-NfH IgG antibody concentration. A calibration curve constructed from the absorbance of our standard diluted geometrically from $1: 50$ to $1: 400$ was run on every plate. Arbitrary units of concentrations were determined from the calibration curve created in the Magellan 6 program (Tecan, Austria).

\section{Expression of the avidity value}

The avidity of antibodies is expressed as an avidity index (AI), which is defined as the ratio of the absorbance or $\mathrm{AU}$ value for the well with a chaotropic agent to the absorbance or AU value of the well without this agent. Usually, AI is expressed in the percentage. The high-avidity antibodies are commonly classified as those with an avidity index higher than $60 \%$ and the low-avidity ones as those with an avidity index lower than $40 \%$. The avidity index values of the antibodies from $40 \%$ to $60 \%$ are usually marked as a "grey zone", when the decision about the avidity is not clear ${ }^{31}$.

\section{Statistical analysis}

Non-parametric statistics were used because the data were not normally distributed. This statement was verified using a graphical evaluation and Shapiro-Wilk's test. The median and interquartile range were used for patients and the control group characterisation. The correlation was tested using the Spearman correlation coefficient. The statistical evaluation of paired measurements was tested using by the Wilcoxon matched pairs test. The MannWhitney test was used for comparisons between groups. The level of significance was set to 0.05. All statistical calculations were done in the Statistica program (StatSoft, Czech Republic).

\section{RESULTS}

\section{Expression of the anti-NfH IgG antibody levels and avidity}

The concentrations of anti-NfH IgG antibodies can be expressed in the values of absorbance $(450 \mathrm{~nm})$ or in the AU obtained from a calibration curve described in the Methods section. Non-linear regression with an extrapolation factor of 2 was used for the construction of a calibration curve. An example of the calibration curve for the expression of anti-NfH IgG antibody concentration in arbitrary units is shown in Fig. 1.

Levels of anti-NfH IgG antibodies in the AU correlated with their expression in the absorbance $(\mathrm{R}=0.6 ; P<0.0001$; $\mathrm{n}=60$; Spearman correlation coefficient). Similarly, the avidity index calculated from absorbance values correlated with the calculation of the avidity index derived from the $\mathrm{AU}(\mathrm{R}=0.976$ for urea $2 \mathrm{~mol} / \mathrm{L}, P<0.0001 ; \mathrm{R}=0.959$ for urea $6 \mathrm{~mol} / \mathrm{L}, P<0.0001$; Spearman correlation coefficient).

\section{Optimisation of the ELISA method for anti-NfH IgG antibody avidity determination}

To optimise the method for avidity determination we focused on (1) the optimal dilution of serum samples; (2) to test the effect of chaotropic solution $\mathrm{pH}$; (3) to find the optimal concentration of chaotropic agents and further (4) to select the suitable chaotropic agent.

\section{Serum dilution}

The best dilutions of sera that corresponded with the linear part of the calibration curve appeared to be 1:200 and 1:400. However, the higher dilution 1:400 was optimal only for samples with elevated levels of antibodies. The absorbance values of sera diluted 1:400 were too low for medium or low levels of antibodies and the results

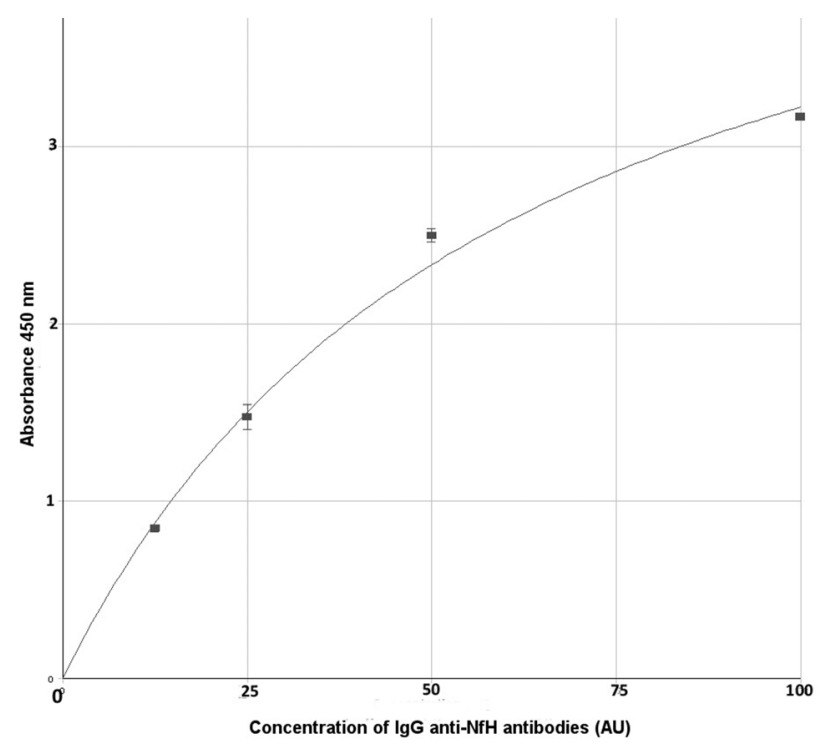

Fig. 1. Example of the calibration curve for the expression of anti-NfH IgG antibody concentration in arbitrary units.

( $\mathrm{R}$ value > 0.95); AU - arbitrary unit; $\mathrm{NfH} \mathrm{-} \mathrm{neurofilament}$ heavy subunit 
were less precise. It was evident for both tested chaotropic agents (urea and $\mathrm{NaCl}$ ) especially, when their higher concentration was used.

\section{pH of the chaotropic agent solutions}

Both chaotropic agent solutions - urea and $\mathrm{NaCl}$ - generated a $\mathrm{pH}$ gradient depending on the concentration of the agent. The mean change in $\mathrm{pH}$ values was 0.25 for $\mathrm{NaCl}$ solutions and 0.1 for urea solutions. The $\mathrm{pH}$ effect of the chaotropic agent solution for avidity determination was tested by analysing five samples (controls and AD patients, low, medium and high values of anti-NfH IgG antibodies). The avidity of each sample was determined using a chaotropic agent solution, in which the $\mathrm{pH}$ was adjusted to a uniform $\mathrm{pH}$ value (7.4) as well as with a chaotropic agent solution with original $\mathrm{pH}$ value arisen at preparation of the solution. The $\mathrm{pH}$ of the chaotropic agent solution in various concentrations did not significantly influence the determination of the anti-NfH IgG antibody avidity. Therefore, it was not necessary to modify the $\mathrm{pH}$ of the chaotropic agent solution in the following experiments.

\section{Concentrations of chaotropic agents}

It was crucial to find a concentration of the chaotropic agent that would clearly differentiate antibodies with high avidity from those with low avidity.

Low concentrations of $\mathrm{NaCl}(0.25 \mathrm{~mol} / \mathrm{L}$ and 0.5 $\mathrm{mol} / \mathrm{L}$ ) showed minimal effect on the disruption of the immune complexes. Differentiation between high- or lowavidity antibodies was allowed by higher concentrations of $\mathrm{NaCl}$ ( $1 \mathrm{~mol} / \mathrm{L}, 2 \mathrm{~mol} / \mathrm{L}$ and $3 \mathrm{~mol} / \mathrm{L}$ ). These concentrations of $\mathrm{NaCl}$ were used for the further assays. After testing an additional four samples, the concentration of 1 $\mathrm{mol} / \mathrm{L}$ and $3 \mathrm{~mol} / \mathrm{L} \mathrm{NaCl}$ were selected for further study because no significant differences between the $1 \mathrm{~mol} / \mathrm{L}$ and $2 \mathrm{~mol} / \mathrm{L} \mathrm{NaCl}$ concentrations were seen.

Higher concentration of urea $(6 \mathrm{~mol} / \mathrm{L}$ and $8 \mathrm{~mol} / \mathrm{L})$ influenced the disruption of immune complexes by a similar intensity. Because of the increased risk of denaturation of immune complexes in the presence of higher concentration of urea, we chose urea concentrations of $6 \mathrm{~mol} / \mathrm{L}$ for avidity determination. A significant difference between 4 $\mathrm{mol} / \mathrm{L}$ and $6 \mathrm{~mol} / \mathrm{L}$ urea concentrations was not found. Finally, the $2 \mathrm{~mol} / \mathrm{L}$ and $6 \mathrm{~mol} / \mathrm{L}$ urea concentrations were chosen for further analyses.

The result of the avidity assay depends on antibody levels ${ }^{18}$. The higher concentration of the chaotrope may be important for samples with high levels of antibodies, in which a lower concentration of the chaotrope could be insufficient for the disruption of a greater amount of immune complexes. Therefore, we performed the avidity determination at two different concentrations of chaotropic agents in the following avidity tests. Significant differences were seen between $1 \mathrm{~mol} / \mathrm{L}$ and $3 \mathrm{~mol} / \mathrm{L} \mathrm{NaCl}(P=0.0001$, Wilcoxon matched paired test) and $2 \mathrm{~mol} / \mathrm{L}$ and $6 \mathrm{~mol} / \mathrm{L}$ urea $(P<0.0001$, Wilcoxon matched paired test $)$ - Fig. 2.

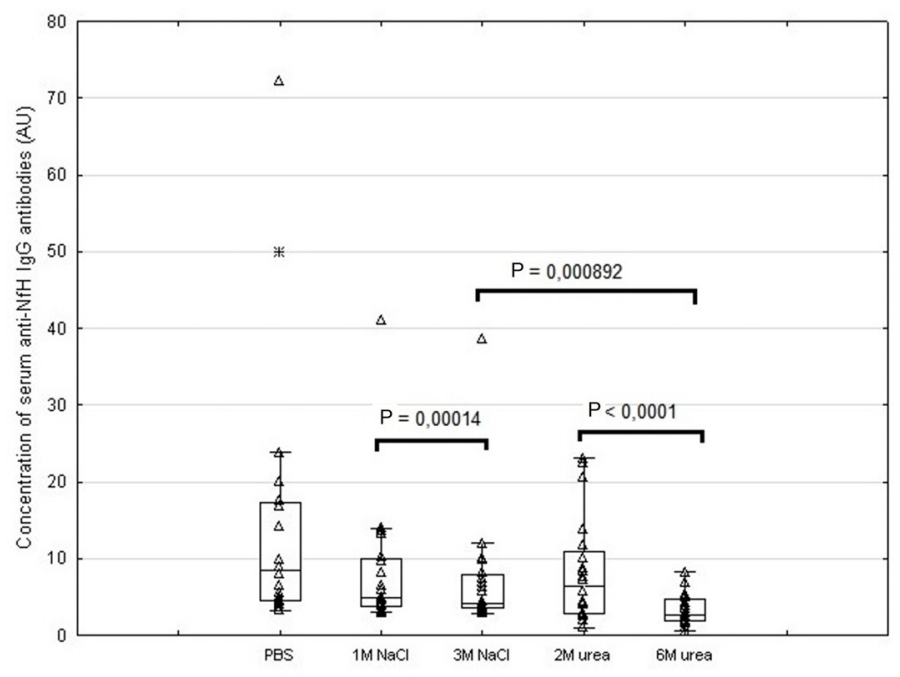

B

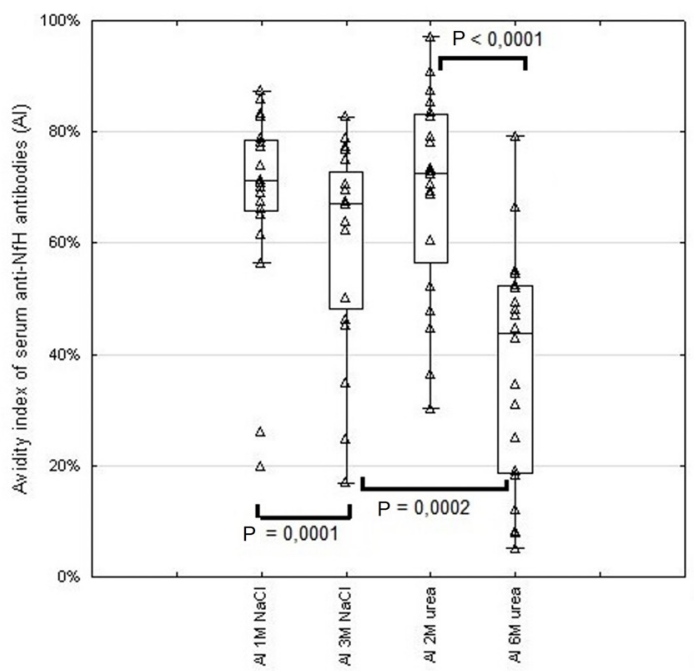

Fig. 2. Comparison of $\mathrm{NaCl}$ and urea as chaotropic agents in the ELISA for the avidity determination of anti-NfH IgG antibodies. The box plots include median (horizontal line - ) , values from the $25^{\text {th }}$ to the $75^{\text {th }}$ percentiles (boxes); bars (whiskers) above and below the box indicate the range of non-outliers. Non-outliers are indicated by triangles. Outliers and extremes are shown by circles and asterisks.

A. Levels of serum anti-NfH IgG antibodies analysed by ELISA method in presence of chaotropic agents ( $\mathrm{NaCl}$ and urea) in different concentrations. The results obtained in absence of chaotropic agents (PBS) are also shown for comparison. The results are expressed in arbitrary units. A significant differences were seen between $1 \mathrm{~mol} / \mathrm{L}$ and $3 \mathrm{~mol} / \mathrm{L}$ of $\mathrm{NaCl}(P=0.00014), 2 \mathrm{~mol} / \mathrm{L}$ and $6 \mathrm{~mol} / \mathrm{L}$ urea $(P<0.0001)$ or $3 \mathrm{~mol} / \mathrm{L} \mathrm{NaCl}$ and $6 \mathrm{~mol} / \mathrm{L}$ urea $(P=0.000892)$.

B. Avidity of serum anti-NfH IgG antibodies analysed by ELISA in the presence of chaotropic agents $(\mathrm{NaCl}$ and urea) in different concentrations. The results of avidity are expressed as an avidity index (\%). Significant differences were seen between $1 \mathrm{~mol} / \mathrm{L}$ and $3 \mathrm{~mol} / \mathrm{L} \mathrm{NaCl}(P=0.0001), 2 \mathrm{~mol} / \mathrm{L}$ and $6 \mathrm{~mol} / \mathrm{L}$ urea $(P<0.0001)$ or $3 \mathrm{~mol} / \mathrm{L} \mathrm{NaCl}$ and $6 \mathrm{~mol} / \mathrm{L}$ urea $(P=0.0002)$.

AU - arbitrary unit; NfH - heavy subunit of neurofilaments; PBS - phosphate buffered saline; M - mol/L 


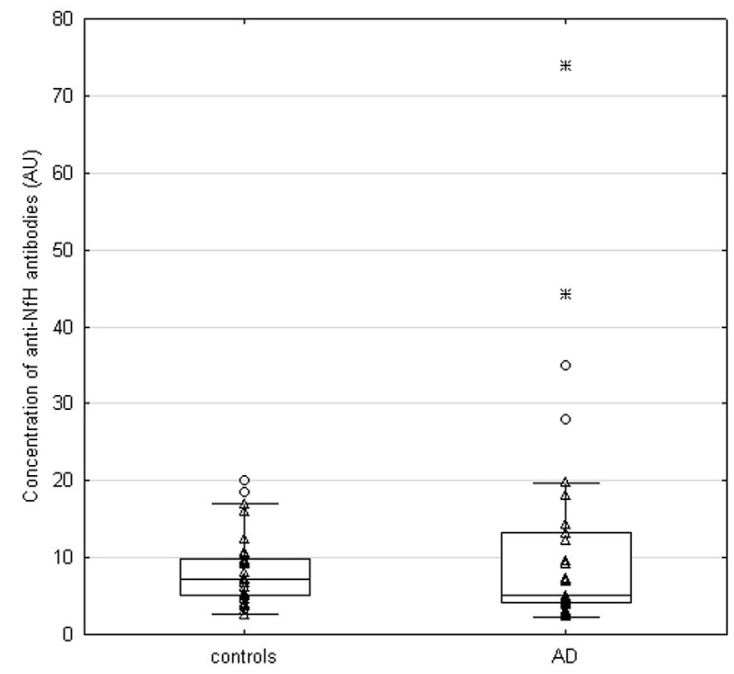

$\mathbf{B}$

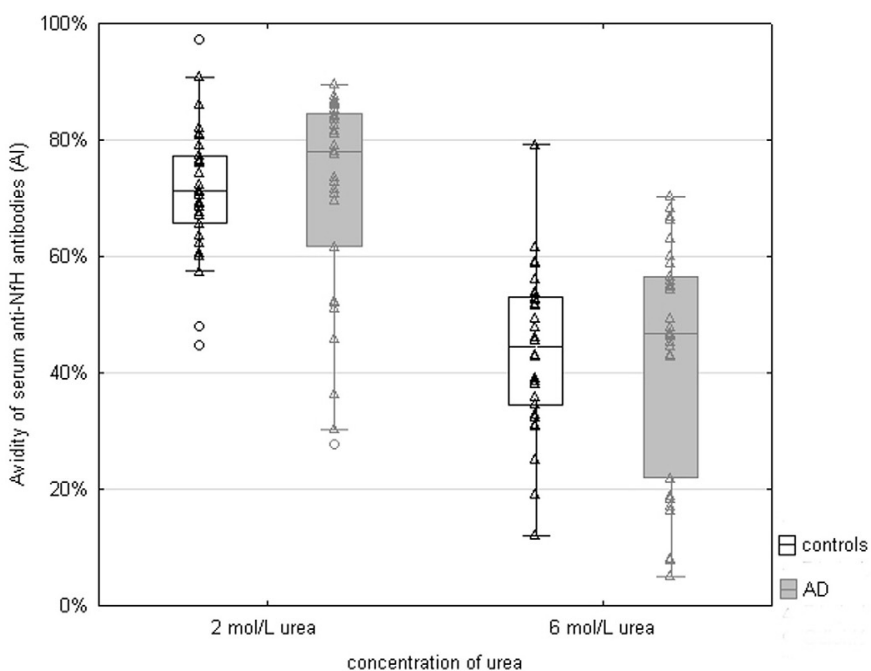

Fig. 3. Comparison of serum levels and avidities of anti-NfH antibodies IgG in the group of Alzheimer's disease patients ( $\mathrm{n}=30$ ) and in the control group $(\mathrm{n}=30)$.

The box plots include median (horizontal line -), values from the $25^{\text {th }}$ to the $75^{\text {th }}$ percentiles (boxes); bars (whiskers) above and below the box indicate the range of non-outliers. Non-outliers are indicated by triangles. Outliers and extremes are shown by circles and asterisks.

A. Levels of serum IgG anti-NfH antibodies without a significant difference between group of Alzheimer's disease patients and the control group

B. Avidity of anti-NfH autoantibodies in serum of Alzheimer's disease patients and the control group. The results of avidity are expressed as an avidity index (\%). A significant difference between these two groups was not found $(P>0.05)$.

AD - Alzheimer's disease; AI - avidity index; AU - arbitrary unit; NfH - neurofilament heavy subunit

A

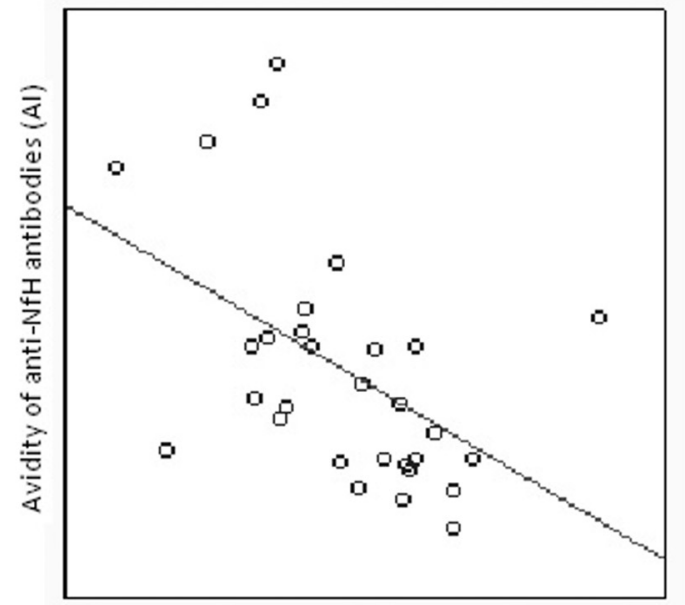

Concentration of anti-NfH antibodies (AU)
B

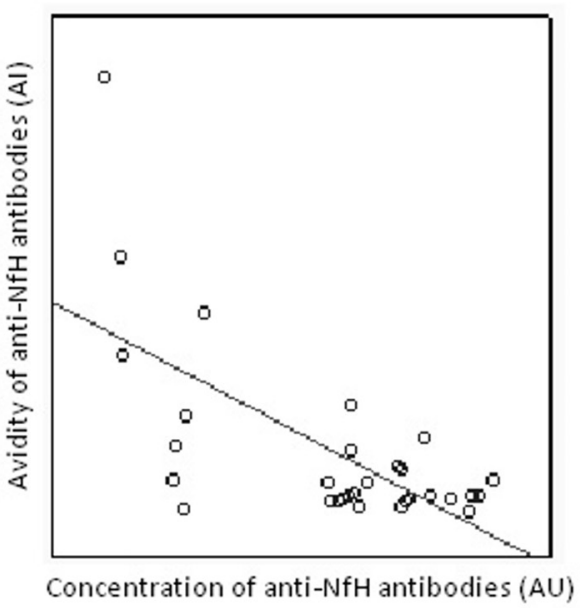

Fig. 4. Relationships between levels and avidities of anti-NfH IgG antibodies. Avidity was determined by ELISA using urea 6 $\mathrm{mol} / \mathrm{L}$ as chaotropic agent.

A. The relationship between levels and avidities of anti-NfH antibodies $\mathrm{IgG}$ in the control group ( $\mathrm{n}=30$ ). A significant inverse correlation was found $(\mathrm{R}=-0.55, P=0.00147)$.

B. The relationship between levels and avidities of $\mathrm{IgG}$ anti-NfH antibodies in the group of the Alzheimer's disease patients ( $\mathrm{n}=30$ ). A significant inverse correlation was found $\mathrm{R}=-0.409, P=0.025$ ).

$\mathrm{AI}$ - avidity index; $\mathrm{AU}$ - arbitrary unit; $\mathrm{NfH}$ - neurofilament heavy subunit 


\section{Comparison of $\mathrm{NaCl}$ and urea as chaotropic agents}

The ability of two chaotropic agents ( $\mathrm{NaCl}$ and urea) to distinguish between high- and low-avidity anti-NfH IgG antibodies was tested. Lower $(1 \mathrm{~mol} / \mathrm{L}$ for $\mathrm{NaCl}$ or 2 $\mathrm{mol} / \mathrm{L}$ for urea) and higher ( $3 \mathrm{~mol} / \mathrm{L}$ for $\mathrm{NaCl}$ or $6 \mathrm{~mol} / \mathrm{L}$ for urea) concentration of these agents were selected and twenty serum samples (10 controls and 10 Alzheimer's disease patients) were analysed. The analyses were assessed in triplicates for the samples and in duplicates for calibration samples.

The influence of chaotropic agents on avidity determination was assessed according to the results both in arbitrary units and avidity indices. Different abilities of chaotropic agents to disrupt the immune complexes were observed. Levels of anti-NfH IgG antibodies (in AU) in the presence of different concentrations of chaotropic agents are shown in Fig. 2.

The values of avidity indices are similar when the 1 $\mathrm{mol} / \mathrm{L} \mathrm{NaCl}$ and $2 \mathrm{~mol} / \mathrm{L}$ urea are used. A significant difference was observed between $3 \mathrm{~mol} / \mathrm{L} \mathrm{NaCl}$ and 6 mol/L urea ( $P=0.00016$; Wilcoxon matched paired test). A reliable estimation of antibody avidity requires about $50 \%$ decrease in an antibody binding after treatment of immune complexes by chaotrophic agents in the ELISA procedure $^{32}$. Thus, urea in the concentration of $6 \mathrm{~mol} / \mathrm{L}$ resulted in the most effective disruption of the immune complexes. Urea was evaluated as a suitable chaotropic agent for the immunochemical (ELISA) determination of anti-NfH IgG antibody avidity (Fig. 2B). The optimised ELISA method using $2 \mathrm{~mol} / \mathrm{L}$ and $6 \mathrm{~mol} / \mathrm{L}$ urea as a chaotropic agent was used for the avidity determination in the serum samples for the clinical part of our study.

Avidity of anti-NfH IgG autoantibodies in serum of Alzheimer's disease patients

Using the optimised ELISA, the avidity of the anti$\mathrm{NfH}$ IgG antibodies was studied in sera of Alzheimer's disease patients and controls.

We found no significant differences either in the levels or in the avidities of serum anti-NfH IgG antibodies between patients with Alzheimer's disease and those in the control group (Fig. 3AB). Also there was no significant correlation between anti-NfH IgG antibodies or their avidity and the relevant sociodemographic characteristics such as age of participants or sex (Spearman correlation coefficient, n.s.).

The levels of anti-NfH IgG antibodies inversely correlated with their avidities. The relationship between levels of antibodies and their avidities was expressed more closely in the control group than that of the AD group. The correlation in the control group was significant for both concentrations of urea used for avidity determination (urea $2 \mathrm{~mol} / \mathrm{L}: \mathrm{R}=-0.38, P=0.038$; urea $6 \mathrm{~mol} / \mathrm{L}: \mathrm{R}=$ $0.55, P=0.00147$, Spearman correlation coefficient). On the contrary, the relationship between levels and avidities of anti-NfH IgG antibodies was only seen in the presence of $6 \mathrm{~mol} / \mathrm{L}$ urea in the AD group (urea $2 \mathrm{~mol} / \mathrm{L}: \mathrm{R}=-0.151$, n.s.; urea $6 \mathrm{~mol} / \mathrm{L}$ : $\mathrm{R}=-0.409, P=0.025$; Spearman correlation coefficient) - Fig. $4 \mathrm{AB}$.

\section{DISCUSSION}

Avidity represents an important feature of antibodies, which significantly influences the formation of immune complexes and affectivity of antibodies. In this study we focused on the avidity of antibodies against $\mathrm{NfH}$, which belong to the cytoskeletal structure specific for nervous tissue $^{5}$. We optimised the avidity assay for IgG antibodies against $\mathrm{NfH}$ by assessing a suitable dilution of sera and by selecting a chaotrope and its concentration; we then examined sera of patients with Alzheimer's disease and control individuals.

Avidity (or functional affinity) is defined as the overall forces that hold together an antigen with a corresponding antibody. It is dependent on the affinity between antigenbinding sites of the antibody and epitopes of the antigen as well as valences of the antigen and the antibody ${ }^{33}$. ELISA is suitable method for the determination of antibody avidity for clinical purposes. Since non-covalent interactions in the certain immune complex are characteristic for a specific antibody and appropriate antigen, it is necessary to test the optimal conditions of the ELISA avidity assay independently for individual antibodies and to select the suitable chaotropic agents and their concentration or suitable dilution of samples. Chaotropic agents such as urea, ammonium thiocyanate, guanidine hydrochloride, diethylamine or sodium chloride have already been used for the determination of antibody avidity $^{7,8,10,18,34,35}$. We chose two chaotropic agents varying in their chemical character - urea as a nonelectrolyte acting as a mild denaturing agent and sodium chloride with an ionic nature. Both chaotropes can impair non-covalent forces such as hydrophobic interactions, hydrogen bridges and Van der Waals forces, which enable the formation of immune complexes ${ }^{18}$. In our experiments urea in a certain concentration disrupted immune complexes of anti-NfH IgG antibodies with $\mathrm{NfH}$ more effectively than tested concentrations of $\mathrm{NaCl}$. The concentration of $6 \mathrm{~mol} / \mathrm{L}$ urea dissociated about $45 \%$ immune complexes and met the requirement about a $50 \%$ decrease in an antibody binding after adding chaotropic agents to immune complexes in the ELISA procedure ${ }^{32}$. Urea is often used for avidity determination, especially for antibodies against infectious agents and it was shown to be a suitable chaotrope for the avidity assay. Therefore, we performed ELISA analyses in samples of our patients with urea solutions ${ }^{13}$.

Research over recent years has suggested the participation of humoral autoimmune processes involved in the pathogenesis of AD (ref. ${ }^{36}$ ). Multiple autoantibodies against various autoantigens were investigated in the serum and/or CSF of AD patients ${ }^{37,38}$. One group of autoantibodies included those against structures specific for nervous tissue, such as neurofilaments ( $\mathrm{NfL}, \mathrm{NfH})$, tau proteins, glial fibrillary acidic proteins and others ${ }^{16,39-42}$. It seems that some autoantibodies may act pathogenically while others could have protective effects ${ }^{37}$. Animal experiments suggested an association between anti-NfH antibodies and some manifestation of AD (ref. ${ }^{43}$ ). Rats immunised with the NfH of Torpedo cholinergic neurons developed specific antibodies, which accumulated 
in the perikarya and neurites of neurons in the septum and hippocampus and in white matter tracts in the rats' forebrains ${ }^{44}$. The immunised rats showed a significant deficit in short-term memory and in a reversal of choice paradigm in a position discrimination test in contrast to long-term memory, which was not affected. Oron et. al. ${ }^{45}$ found that cognitive deficit in rats with experimental autoimmune dementia after immunisation by the cholinergic $\mathrm{NfH}$ evolved more slowly than the decrease in the density of cholinergic neurons in the septum of rats and the accumulation of $\mathrm{IgG}$ in the same brain area.

The use of certain autoantibodies as diagnostic or prognostic markers is under investigation. Levels of these antibodies were studied in sera and/or CSF (ref. ${ }^{27,28,46}$ ). We were mainly interested in the antibodies against autoantigens originating from the neurocytoskeleton in past. We found the differences in avidities of anti-NFM and anti-tau antibodies in serum and CSF in the patients with multiple sclerosis ${ }^{29}$. In addition, differences in avidities of various anti-neurocytoskeletal antibodies were seen. These are not surprising findings. Totland et. al. ${ }^{47}$ also observed various avidities of two onconeuronal antibodies $\mathrm{Hu}$ and Yo in patients with paraneoplastic neurological syndromes. Therefore, it is important to test the avidity of each autoantibody individually.

The pathogenic autoantibodies are mostly characterised by a higher avidity for autoantigens in the target tissue $^{9,48-50}$, but the occurrence of low-avidity autoantibodies in immune-mediated diseases have also been described ${ }^{15,51}$. Jianping et. al. ${ }^{15}$ investigated the avidity of anti-A $\beta$ antibodies in AD and found that both levels and avidities of anti-A $\beta$ antibodies were statistically lower in AD patients than in the age-matched control group. They assumed that avidity declination would have a great influence on the clearance of $\mathrm{A} \beta$ by the cells of the immune system. We assumed similar changes in avidity of serum anti-NfH antibodies. Unfortunately, the comparison of anti-NfH IgG antibody levels and avidities showed no differences between $\mathrm{AD}$ patients and control. However, the avidity of antibodies may change with the progression of the disease. The follow-up study of individual AD patients might find a certain trend in the avidity of anti-NfH IgG antibodies in the serum.

A statistically significant inverse relationship between avidities and levels of anti-NfH antibodies in both groups was found. This might reflect that high-avidity anti-NfH IgG antibodies are bound in the immune complexes with their antigens. Conversely, the low-avidity antibodies form immune complexes less effectively and they tend to reach higher levels as free molecules.

\section{CONCLUSION}

We optimised the ELISA method in order to find anti-NfH antibody avidity determination. This method has been used for the study of anti-NfH antibody avidity in serum of patients with Alzheimer's disease, but it is also suitable for research of anti-NfH antibody avidity in patients with other neurological diseases associated with neurocytoskeletal defects. Neither levels nor avidity of IgG anti-NfH antibodies differed between AD patients and cognitively normal persons. In the future, we plan to investigate if the levels and avidity of antineurocytoskeletal antibodies will change during the follow-up study. In addition, we are going to determine separately, free anti-NfH IgG antibodies and those bound in immune complexes.

Acknowledgement: The study was supported by the following: Charles University Grant Agency GAUK 275015, Specific Academic Research Projects 260263, PROGRES Q25/LF1, PROGRES Q35 and the project of Ministry of Health, Czech Republic for conceptual development of research organization RVO-VFN64165 - General University Hospital in Prague, Czech Republic.

Author contributions: LN: study design, laboratory analysis, data analysis and interpretation, writing of the manuscript; LF: study design, data analysis and interpretation, writing of the manuscript; $\mathrm{AB}$ : collection and analysis of clinical data, clinical evaluation, general corrections; TZ: supervising the study.

Conflict of interest statement: The authors state that there are no conflicts of interest regarding the publication of this article.

\section{REFERENCES}

1. Eira J, Silva CS, Sousa MM, Liz MA. The cytoskeleton as a novel therapeutic target for old neurodegenerative disorders. Prog Neurobiol 2016;141:61-82.

2. Liu Q, Xie F, Alvarado-Diaz A, Smith MA, Moreira PI, Zhu X, Perry G. Neurofilamentopathy in neurodegenerative diseases. Open Neurol J 2011;5:58-62.

3. Zaffaroni M. Biological indicators of the neurodegenerative phase of multiple sclerosis. Neurol Sci 2003;24 Suppl 5:S279-82.

4. Huizinga $R$, Linington $C$, Amor $S$. Resistance is futile: antineuronal autoimmunity in multiple sclerosis. Trends Immunol 2008;29:54-60.

5. Petzold A. Neurofilament phosphoforms: surrogate markers for axonal injury, degeneration and loss. J Neurol Sci 2005;233:183-98.

6. Sigurdsson EM. Tau Immunotherapy. Neurodegener Dis 2016;16:348.

7. Cucnik S, Kveder T, Artenjak A, Ulcova Gallova Z, Swadzba J, Musial J, Iwaniec T, Stojanovich L, Alessandri C, Valesini G, Avcin T, Cohen Tervaert JW, Rozman B, Bozic B. Avidity of anti-beta2-glycoprotein I antibodies in patients with antiphospholipid syndrome. Lupus 2012;21:764-5.

8. Cucnik S, Kveder T, Ulcova-Gallova Z, Swadzba J, Musial J, Valesini G, Avcin T, Rozman B, Bozic B. The avidity of anti-beta2-glycoprotein I antibodies in patients with or without antiphospholipid syndrome: a collaborative study in the frame of the European forum on antiphospholipid antibodies. Lupus 2011;20:1166-71.

9. Cui Z, Zhao MH. Avidity of anti-glomerular basement membrane autoantibodies was associated with disease severity. Clin Immunol 2005; 116:77-82.

10. Woznicová V. [Immunoglobulin $G$ avidity in infectious diseases]. [Article in Czech]. Epidemiol Mikrobiol Imunol 2004;53:4-11.

11. Boxus M, Lockman L, Fochesato M, Lorin C, Thomas F, Giannini SL. Antibody avidity measurements in recipients of Cervarix vaccine following a two-dose schedule or a three-dose schedule. Vaccine 2014;32:3232-6.

12. Curdt I, Praast G, Sickinger E, Schultess J, Herold I, Braun HB, Bernhardt S, Maine GT, Smith DD, Hsu S, Christ HM, Pucci D, Hausmann M, Herzogenrath J. Development of fully automated determination of marker-specific immunoglobulin $\mathrm{G}(\mathrm{IgG})$ avid- 
ity based on the avidity competition assay format: application for Abbott Architect cytomegalovirus and Toxo lgG Avidity assays. J Clin Microbiol 2009;47:603-13.

13. Flori P, Tardy L, Patural H, Bellete B, Varlet MN, Hafid J, Raberin H, Sung RT. Reliability of immunoglobulin $\mathrm{G}$ antitoxoplasma avidity test and effects of treatment on avidity indexes of infants and pregnant women. Clin Diagn Lab Immunol 2004;11:669-74.

14. Menge T, Lalive PH, von Budingen HC, Genain CP. Conformational epitopes of myelin oligodendrocyte glycoprotein are targets of potentially pathogenic antibody responses in multiple sclerosis. $J$ Neuroinflammation 2011;8:161.

15. Jianping $L$, Zhibing Y, Wei Q, Zhikai C, Jie X, Jinbiao L. Low avidity and level of serum anti-Abeta antibodies in Alzheimer disease. Alzheimer Dis Assoc Disord 2006;20:127-32.

16. Bartos A, Fialova L, Svarcova J, Ripova D. Patients with Alzheimer disease have elevated intrathecal synthesis of antibodies against tau protein and heavy neurofilament. J Neuroimmunol 2012;252:100-5.

17. Soussan L, Tchernakov K, Bachar-Lavi O, Yuvan T, Wertman E, Michaelson DM. Antibodies to different isoforms of the heavy neurofilament protein (NF-H) in normal aging and Alzheimer's disease. Mol Neurobiol 1994;9:83-91.

18. Dimitrov JD, Lacroix-Desmazes S, Kaveri SV. Important parameters for evaluation of antibody avidity by immunosorbent assay. Ana Biochem 2011;418:149-51.

19. Bartoš A, Zach P, Diblíková F, Tintěra J, Řípová D, Brunovský M. Visua rating of medial temporal lobe atrophy on magnetic resonance imaging in Alzheimer's disease. Psychiatrie 2007;11:49-52.

20. Bartoš A, Čechová L, Švarcová J, Říčný J, Řípová D. Cerebrospinal fluid triplet (tau proteins and beta-amyloid) in the diagnosis of AlzheimerFischer disease [Likvorový triplet (tau proteiny a beta-amyloid) $v$ diagnostice Alzheimerovy-Fischerovy nemoci]. Cesk Slov Neurol N 2012;75/108:587-94.

21. Scheltens $P$, Leys $D$, Barkhof $F$, Huglo D, Weinstein HC, Vermersch P, Kuiper M, Steinling M, Wolters EC, Valk J. Atrophy of medial temporal lobes on MRI in "probable" Alzheimer's disease and normal ageing: diagnostic value and neuropsychological correlates. J Neurol Neurosurg Psychiatry 1992;55:967-72.

22. Dubois B, Feldman HH, Jacova C, Dekosky ST, Barberger-Gateau $P_{\text {, }}$ Cummings J, Delacourte A, Galasko D, Gauthier S, Jicha G, Meguro K, O'Brien J, Pasquier F, Robert P, Rossor M, Salloway S, Stern Y, Visser PJ, Scheltens P. Research criteria for the diagnosis of Alzheimer's disease: revising the NINCDS-ADRDA criteria. Lancet Neurol 2007;6:734-46.

23. McKhann G, Drachman D, Folstein M, Katzman R, Price D, Stadlan EM. Clinical diagnosis of Alzheimer's disease: report of the NINCDS ADRDA Work Group under the auspices of Department of Health and Human Services Task Force on Alzheimer's Disease. Neurology 1984;34:939-44.

24. McKhann GM, Knopman DS, Chertkow H, Hyman BT, Jack CR, Jr. Kawas $\mathrm{CH}$, Klunk WE, Koroshetz WJ, Manly JJ, Mayeux R, Mohs RC, Morris JC, Rossor MN, Scheltens P, Carrillo MC, Thies B, Weintraub S, Phelps $\mathrm{CH}$. The diagnosis of dementia due to Alzheimer's disease: recommendations from the National Institute on Aging-Alzheimer's Association workgroups on diagnostic guidelines for Alzheimer's disease. Alzheimers Dement 2011;7:263-9.

25. Bartoš A, Raisová M. The Mini-Mental State Examination (MMSE) - Czech norms and cut-offs for mild dementia and mild cognitive impairment due to Alzheimer disease. Dementia and Geriatric Cognitive Disorders 2016;42:50-7.

26. Povova J, Ambroz P, Bar M, Pavukova V, Sery O, Tomaskova H, Janout V. Epidemiological of and risk factors for Alzheimer's disease: a review. Biomed Pap Med Fac Univ Palacky Olomouc Czech Repub 2012;156:108-14

27. Silber E, Semra YK, Gregson NA, Sharief MK. Patients with progres sive multiple sclerosis have elevated antibodies to neurofilament subunit. Neurology 2002;58:1372-81.

28. Bartos A, Fialova L, Soukupova J, Kukal J, Malbohan I, Pitha J. Antibodies against light neurofilaments in multiple sclerosis patients. Acta Neurol Scand 2007;116:100-7.

29. Fialova L, Svarcova J, Bartos A, Malbohan I. Avidity of anti-neurocytoskeletal antibodies in cerebrospinal fluid and serum. Folia Microbiol (Praha) 2012;57:415-9.

30. Cucnik S, Bozic B, Kveder T, Tomsic M, Rozman B. Avidity of antibeta2-glycoprotein I and thrombosis or pregnancy loss in patients with antiphospholipid syndrome. Ann NY Acad Sci 2005;1051:141-7.
31. Almanzar G, Ottensmeier B, Liese J, Prelog M. Assessment of IgG avidity against pertussis toxin and filamentous hemagglutinin via an adapted enzyme-linked immunosorbent assay (ELISA) using ammonium thiocyanate. J Immunol Methods 2013;387:36-42.

32. Pullen GR, Fitzgerald MG, Hosking CS. Antibody avidity determination by ELISA using thiocyanate elution. J Immunol Methods 1986;86:83-7.

33. Gharavi A, Reiber H. Affinity and avidity of autoantibodies. In: Peter J, Shoenfeld Y, eds. Autoantibodies. Amsterdam: Elsevier, 1996: 13-23.

34. Cucnik S, Kveder T, Krizaj I, Rozman B, Bozic B. High avidity anti-beta 2-glycoprotein I antibodies in patients with antiphospholipid syndrome. Ann Rheum Dis 2004;63:1478-82.

35. Dauner JG, Pan Y, Hildesheim A, Kemp TJ, Porras C, Pinto LA. Development and application of a GuHCl-modified ELISA to measure the avidity of anti-HPV L1 VLP antibodies in vaccinated individuals. Mol Cell Probes 2012;26:73-80.

36. D'Andrea MR. Add Alzheimer's disease to the list of autoimmune diseases. Med Hypotheses 2005;64:458-63.

37. Colasanti T, Barbati C, Rosano G, Malorni W, Ortona E. Autoantibodies in patients with Alzheimer's disease: pathogenetic role and potential use as biomarkers of disease progression. Autoimmun Rev 2010;9:807-11.

38. Papuc E, Kurys-Denis E, Krupski W, Tatara M, Rejdak K. Can Antibodies Against Glial Derived Antigens be Early Biomarkers of Hippocampal Demyelination and Memory Loss in Alzheimer's Disease? J Alzheimers Dis 2015;48:115-21.

39. Ishida K, Kaneko K, Kubota T, Itoh Y, Miyatake T, Matsushita M, Yamada M. Identification and characterization of an anti-glial fibrillary acidic protein antibody with a unique specificity in a demented patient with an autoimmune disorder. J Neurol Sci 1997;151:41-8.

40. Mecocci P, Parnetti L, Donato R, Santucci C, Santucci A, Cadini D, Foa E, Cecchetti R, Senin U. Serum autoantibodies against glial fibrillary acidic protein in brain aging and senile dementias. Brain Behav Immun 1992;6:286-92.

41. Rosenmann H, Meiner Z, Geylis V, Abramsky O, Steinitz M. Detection of circulating antibodies against tau protein in its unphosphorylated and in its neurofibrillary tangles-related phosphorylated state in Alzheimer's disease and healthy subjects. Neurosci Lett 2006;410:903.

42. Tanaka J, Nakamura K, Takeda M, Tada K, Suzuki H, Morita H, Okado T, Hariguchi S, Nishimura T. Enzyme-linked immunosorbent assay for human autoantibody to glial fibrillary acidic protein: higher titer of the antibody is detected in serum of patients with Alzheimer's disease. Acta Neurol Scand 1989;80:554-60.

43. d'Abramo C, Acker CM, Jimenez HT, Davies P. Tau passive immunotherapy in mutant P301L mice: antibody affinity versus specificity. PLoS One 2013;8:e62402.

44. Chapman J, Alroy G, Weiss Z, Faigon M, Feldon J, Michaelson DM. Anti-neuronal antibodies similar to those found in Alzheimer's disease induce memory dysfunction in rats. Neuroscience 1991;40:297305.

45. Oron L, Dubovik V, Novitsky L, Eilam D, Michaelson DM. Animal model and in vitro studies of anti neurofilament antibodies mediated neurodegeneration in Alzheimer's disease. J Neural Transm Suppl 1997;49:77-84.

46. Bartos A, Fialova L, Soukupova J, Kukal J, Malbohan I, Pit'ha J. Elevated intrathecal antibodies against the medium neurofilament subunit in multiple sclerosis. J Neurol 2007;254:20-5.

47. Totland C, Aarseth J, Vedeler C. Hu and Yo antibodies have heterogeneous avidity. J Neuroimmunol 2007;185:162-7.

48. Bozic B, Cucnik S, Kveder T, Rozman B. Avidity of anti-beta-2-glycoprotein I antibodies. Autoimmun Rev 2005;4:303-8.

49. Božič B, Čučnik S, Kveder T, Rozman B. Affinity and avidity of autoantibodies. In: Shoenfeld Y, Gershwin ME, Meroni PL, eds. Autoantibodies. Amsterdam: Elsevier, 2007: 21-28.

50. Schlosser M, Koczwara K, Kenk H, Strebelow M, Rjasanowski I, Wassmuth R, Achenbach P, Ziegler AG, Bonifacio E. In insulinautoantibody-positive children from the general population, antibody affinity identifies those at high and low risk. Diabetologia 2005;48:1830-2.

51. Cao Z, Lv J, Quan W. Low avidity and level of serum anti-Abeta antibodies in patients with cerebral amyloid angiopathy-related cerebral hemorrhage. Int J Neurosci 2010;120:760-4. 